Y hago versos y así pierdo la vida desterrado en Sun Yan.

A veces, cuando acabo un poema, subo, loco, corriendo, al Peñón del Oriente y lo digo en voz alta frente a la inmensidad. En la quietud, los pájaros se desconciertan y los montes se extrañan y los monos me espían.

Soy un escándalo de la naturaleza, y de mí mismo, y de los míos.

\title{
JIRA DE TRABAJO
}

Flores sin flores, neblina sin neblina.

Oscuridad donde nada se salva.

Primavera soñada, matutina.

Llegar a media noche, partir antes del alba.

\section{AMOR DISTANTE}

Quiero olvidar, pero es en vano.

Quisiera ir, pero no puedo.

No tengo alas en los hombros.

Ya tengo blanco el pelo.

Me siento a ver caer las hojas.

Subo a la torre: el campo inmenso.

Crecen las sombras del crepúsculo.

Algo me va dejando ciego. 